\title{
Fulfillment of Child Refugee Rights in Indonesia and Regulatory Implementation Regarding the Handling of Foreign Refugees
}

\author{
Titik Suharti $^{*}$
}

\author{
Faculty of Law, Universitas Wijaya Kusuma Surabaya, Jl. Dukuh Kupang XXV - 54 Surabaya, East Java \\ 60225, Indonesia
}

\begin{abstract}
The purpose of this paper is to find out how the implementation of the regulation on the fulfillment of children's refugee rights in Indonesia. This research uses the normative legal research method and the legislative approach. The results showed that the existing regulations have not sufficiently fulfilled the rights of child refugees because it does not regulate in detail the fulfillment of the rights specifically possessed by a child. For instance, the Presidential Regulation only concerns the discovery, holding, security, and supervision of refugees while at the refugee camp. The conclusion obtained is the need for additional rules regarding the operational standards for handling refugees that regulate what things can be done and prohibited by refugees while in shelters. This is closely related to the guarantee of refugee rights by Indonesia including child refugees.
\end{abstract}

Keywords: Refugees, children's rights, asylum seekers, Indonesia.

\section{INTRODUCTION}

In the past ten years, waves of refugees have occurred in several countries such as those in Bangladesh, Malaysia, Australia and Indonesia (Devetak, 2004; Jeffers, 2012). Waves of refugees occur because of conflicts that occur in the country of origin. Conflicts that usually occur are caused by territorial struggles, acts of discrimination related to ethnicity or religion, and efforts to become independent from one country. This conflict not only raises fear and threatens people in conflict areas but is also usually accompanied by an increase in poverty and a decrease in the quality of life. This causes the people in it to want to get out of conflict countries to save themselves. The United Nations High Commissioner for Refugees (UNHCR) notes that the conflict that caused a wave of refugees occurred in several countries such as Syria, Afghanistan, Myanmar, Central African, Iraq, Burundi, Yemen, etc. (https://www.unhcr.org/emergencies.html). The handling of child refugees is certainly different from adult refugees because of different basic needs. This indicates the need for a different legal umbrella for the handling of refugee children with adult refugees.

The phenomenon of waves of refugees has become a concern for countries around the world, especially regarding the handling and determination of the fate of immigrants who came out of conflict areas. There are international conventions governing refugee management, the 1951 Convention Relating to the Status of Refugee (hereinafter abbreviated as Refugee Convention) and the 1967 Protocol Relating to the

${ }^{*}$ Address correspondence to this author at the Faculty of Law, Universitas Wijaya Kusuma Surabaya, JI. Dukuh Kupang XXV - 54 Surabaya, East Java 60225, Indonesia E-mail: tsuharti.uwks@gmail.com
Status of Refugee (hereinafter abbreviated as Refugee Protocol) (UN General Assembly, 1951; Moussalli, 1992; Zimmermann et al., 2011). The two rules do not specifically regulate the handling of child refugees, but the contents of these rules cover the handling of child refugees. There are rules governing children's rights, namely the Convention on the Rights of the Child in 1989 (UN General Assembly, 1989). Regarding the protection of child refugees, in Article 22 the Convention requires States parties to provide refugee children, both those who are refugees or who are seeking refugee status, adequate humanitarian assistance to enjoy the rights in the Convention, in human rights or other humanitarian instruments. Moreover, the Convention does not specifically regulate the guarantee of the rights of child refugees but the content of the rights guaranteed by this convention applies to all children including child refugees.

Indonesia is not a country ratifying the Refugee Convention and Refugee Protocol, but Indonesia is a host country for many immigrants (Brown, 2017; Briskman \& Fiske, 2016). The immigrants entered Indonesian territory to get assistance from the Government of Indonesia while waiting for the refugee status granted by UNHCR to be subsequently accepted in third countries such as the United States, European countries and Australia. Regarding refugees, Indonesia is not obliged to provide treatment, shelter or other forms of assistance because Indonesia is not the country of the two regulations. Another case when it comes to child refugees. Indonesia is obliged to guarantee the rights of child refugees because Indonesia is a state party to the Convention. In terms of handling refugees in Indonesia, Indonesia already has 
a legal umbrella, namely Presidential Regulation No. 125 of 2016 concerning Handling of Refugees from Overseas (hereinafter abbreviated to President. Reg No. 125 of 2016) (Shahnaz et al., 2019; Afriansyah, 2018). This regulation regulates the handling of refugees starting from the discovery, security and supervision at the shelter. This regulation was ratified as a substitute for the non-ratification of the Refugee Convention and the Refugee Protocol. From the background, this study uses a normative research method with a statutory approach. There are two problems in this study, namely, what are the rights of child refugees that should be guaranteed by the Government of Indonesia and how the implementation of Presidential Regulation No. 125 of 2016 on the fulfillment of the rights of child refugees in Indonesia.

\section{LITERATURE REVIEW: RIGHTS OF CHILD REFUGEES}

Every child has rights that must be guaranteed by countries. Countries in the world have made the guarantee of children's rights one of the priorities to be implemented. In 1989 it was successfully approved and opened for the signing, ratification and accession of the 1989 Convention on the Rights of Child. The Convention came into force on September 2, 1990. Indonesia became one of the Convention countries. The Convention regulates which rights must be guaranteed by member countries. Article 1 of the Convention defines "child" as any human being under the age of 18 unless according to the law in force the child is determined that adulthood is reached earlier. The Convention does not limit that "children" whose rights are guaranteed through the convention must have citizenship. This means that children who become immigrants and wait for refugee status also have rights that must be guaranteed under the Convention.

As a member state of the Convention, Indonesia is obliged to guarantee the rights contained in the convention which are owned by all children including child refugees in Indonesia. Based on Article 6 of the Convention, Indonesia is obliged to recognize that all children have the right to live and to ensure the maximum possible survival and development of children. Once a child refugee enters into Indonesian territory both in a healthy or sick condition, the Indonesian government is obliged to guarantee the safety of the child refugee. Indonesia also has to make every effort so that refugee children in Indonesia are in an environment that does not interfere with the child's growth and development. Article 7 of the Convention provides that every child has the right to obtain a name to obtain citizenship. Matters concerning citizenship are closely related to refugees. In this case, Indonesia can facilitate UNHCR in implementing procedures for handling immigrant children in Indonesia so that they can immediately obtain refugee status and become citizens of third countries.

Indonesia must ensure that those child refugees are not separated from their parents, especially during the shelter period. In the period of immigrant shelter, it is very vulnerable to occur immigrants out of the territory of Indonesia illegally for the purpose of going to a third country. Under Article 11 of the Convention, Indonesia is obliged to eradicate the occurrence of child surrenders abroad. Every child has the right to express his opinion and hear his opinion. Not only that, every child also has the right to associate, gather, and also carry out religious activities as stated in Article 13-15 of the Convention. If there are refugee children in Indonesia who have a religion other than the religion recognized by Indonesia, Indonesia must still ensure that the child can carry out religious activities he believes.

The Convention was not specifically created to guarantee the rights of child refugees, but there is an article in it that reinforces the recognition of the rights of child refugees. Article 22 of the Convention provides that states parties must take steps to ensure that children who seek refugee status or are considered refugees in accordance with applicable international and national law will receive appropriate humanitarian protection or assistance. States parties must cooperate with international organizations that are authorized to protect and assist such children and to track and locate parents of such children. Indonesia as a transit country for refugees can work together with UNHCR as an international organization authorized to handle refugees to provide protection and humanitarian assistance for child refugees in their territory. Under Article 24 of the Convention, children have the right to enjoy the highest attainable health standards and care facilities when ill. The majority of refugees enter illegally into Indonesian territory by sea. They usually use ships with very inadequate and overcapacity conditions and do not bring food supplies so that some refugees when entering Indonesia are sick, injured or even die. Conditions like this the Indonesian government must provide health assistance and proper care for refugees with sick or injured conditions. 
Every child refugee is also entitled to a decent life for their physical, mental, spiritual, moral and social development, as stated in Article 27 of the Convention. This needs to be supported by a holding environment that is suitable for the purpose of fulfilling these rights. The holding environment is very influential on the growth and development of child refugees. The holding environment must pay attention to the comfort, cleanliness, and safety of the child himself. States parties also need to ensure that child refugees have a suitable place for growth and development when they have obtained citizenship from a third country. Every child has the right to get protection from economic and sexual exploitation as stated in Article 32 and 34 of the Convention. Child refugees are very vulnerable to becoming victims of human trafficking and sexual exploitation so that they need protection and security from state parties. Generally, they are trapped and deceived by elements who promise refugees to be able to get out of the transit country and go to a third country. But in reality, these refugees are victims of human trafficking and sexual exploitation (Joko Priyono \& Sudiro, 2020).

To find out what are the rights of child refugees is not enough by looking at the provisions in the Convention. Indonesia already has Law No. 23of 2002 concerning Child Protection and Law No. 35 of 2014 concerning Amendments to Law No. 23of 2002 concerning Child Protection. Article 1 of Law No. 35 of 2014 defines "child" as not different from the Convention. The child is interpreted as someone who is not yet 18 years old, including children who are still in the womb. All children are included in the scope of Law No. 35 of 2014 as well as Law No. 23 of 2002 not only children who are in Indonesia or who are Indonesian citizens. This means that both laws also apply to refugee children in Indonesia.

The Indonesian government is obliged to provide protection for child refugees in its territory. Child refugees who are in Indonesia have rights guaranteed by Law NO. 35 of 2014 as well as Law No. 23 of 2002. Based on Article 4 of Law No. 23 of 2002, every child has the right to live, grow, develop, and participate appropriately in accordance with human dignity and dignity, and is protected from violence and discrimination. Child refugees are entitled to receive protection from the Government of Indonesia in order to stay alive and grow and be protected from violence and discrimination. Refugee children out of their territory for various reasons that make them not want to return to their home country. Child refugees enter
Indonesian territory generally to be able to transit while waiting for refugee status granted by UNHCR. Refugee status is used to be able to live in a third country, which is a member country of the Refugee Convention and Refugee Protocol and is a citizen of that country. The Indonesian government as a host country or country where refugee children are transiting, is also obliged to make sure that child refugees immediately get citizenship because based on Article 4 of Law No. 23 Know 2002 every child has the right to a name as selfidentity and citizenship status.

Every child has the right to worship according to his religion, think, and express according to the level of intelligence and age under the guidance of parents and guardians (Art. 6 of Act Act No. 35 of 2014). Every child has the right to receive health and social security services according to their physical, mental, spiritual and social needs. Based on Article 9 of Law No. 35 of 2014, every child has the right to education and teaching and to be protected in an education unit from sexual crimes and violence. If there is a compulsory education program for Indonesian children, according to this rule, refugee children who are in Indonesia are also entitled to have similar educational facilities. Based on Article 15 of Law No. 35 of 2014, every child has the right to obtain protection from abuse in political activities, involvement in armed disputes, involvement in social unrest, involvement in warfare, and sexual crimes. Child refugees are entitled to obtain protection from armed disputes that are taking place in their home countries. The Indonesian government can strive for child refugees in Indonesia to be immediately approved by the UN through UNHCR in Indonesia to be placed in safer destination countries because every child is also entitled to protection from targets of torture, torture, and inhuman punishment (Art 16 Act No. 23 of 2002).

Efforts to protect children's rights for refugee children in Indonesia require commitment from the Indonesian government. This effort requires good cooperation and coordination between the central government and regional governments. Article 20 and 21 of Law No. 35 of 2014 requires the state, government, regional government, community, family, and parents or guardians to be responsible for the implementation of child protection and requires cooperation between the central government and regional governments to realize respect and protection of children's rights. Related to child refugees, Law no. 35 of 2014 specifically provides legal protection for child refugees. Based on Articles 59 and 60 of Law No. 35 In 2016, children who become refugees are 
classified as children who are in an emergency situation which will be given special protection by the Government, Regional Government, and other institutions. Article 59 of Law No. 35 of 2014 stated that special protection provided to children who become refugees is done through rapid handling efforts, including treatment and/or rehabilitation physically, psychologically, and socially, as well as prevention of diseases and other health problems. Specifically, for children who become refugees, Article 61 of Law No. 23 of 2002 stated that special protection provided is carried out in accordance with humanitarian law. Legal protection for good children in Law NO. 35 of 2014 as well as Law No. 23 of 2002 in line with those in the Convention. That is because Indonesia had ratified the convention in 1990 so that laws issued by Indonesia must not conflict with the Convention.

\section{IMPLEMENTATION OF PRESIDENTIAL REGULATION NO. 125 OF 2016 CONCERNING THE FULFILLMENT OF CHILD REFUGEE RIGHTS IN INDONESIA}

Indonesia shows its human side by committing to give attention to the phenomenon of refugee waves that occur in several countries including in the territory of the country. In 2016, the Government of Indonesia ratified Presidential Regulation Number 125 Year 2016 Regarding Handling of Refugees from Overseas (hereinafter abbreviated to President. Reg No. 125 of 2016) as a substitute for the non-ratification of the Refugee Convention and Refugee Protocol. This rule is used as a legal basis for handling refugees in Indonesia.President. Reg No. 125 of 2016 defines refugees as foreigners residing in the territory of the Unitary Republic of Indonesia due to reasonable fear of persecution for reasons of race, ethnicity, religion, nationality, membership of certain social groups and different political opinions and does not want protection from their home country and/or have obtained asylum seeker status or refugee status from the UN through UNHCR. The definition of refugees in President. Reg No. 125 of 2016 is the same as the definition of refugee given by the Refugee Convention

President. Reg No. 125 of 2016 regulates how to handle refugees from abroad who enter Indonesian territory. The said treatment starts from discovery, storage, security, to immigration control. Based on Articles 5, 9, 10 and 11 of Presidential Regulation No. 125 of 2016, if refugees are found in an emergency in the territorial waters of Indonesia, several actions will be taken including moving refugees to rescue vessels if the ship will sink; bring to the nearest port or land if the lives of refugees are threatened; identify refugees who need emergency medical assistance; surrender foreigners suspected of being refugees to immigration detention centers at the nearest port or land or if there are none then hand them over to the immigration office in the region or to the local Indonesian National Police.

The majority of refugees enter Indonesian territory by sea. One example is the Rohingya refugee. Rohingya refugees enter the territory of Indonesia by sea because they are prohibited from traveling by land by the Myanmar government (Armandhanu, 2016). Indonesia is only a transit country for Rohingya refugees. Indonesian waters are the route they have to travel to Malaysia and Australia where they are the destination country to get a decent living. Many of the Rohingya refugees had to be assisted by Indonesia because the ship they were riding was in trouble and their safety was threatened. In May 2015, Acehnese fishermen rescued two ships that housed Rohingya refugees. A total of 800 refugees were rescued and accommodated in the Aceh region. Refugees who immediately need medical treatment have received medical assistance from relevant agencies (Pasuhuk, 2015). The majority of Rohingya refugees enter Indonesian waters after receiving refusal from Malaysia and Thailand when they will enter their waters (Molana, 2018).

Indonesia's actions to save Rohingya refugees were found in Indonesian waters, with their safety conditions threatened, by bringing them to the mainland and immediately providing the needed medical help according Regulation No. 125 of 2016.

Based on Article 24 of Presidential Regulation No. 125 In 2016, refugees will be placed in shelters. If a shelter is not yet available, it will be placed in a temporary accommodation location determined by the local regent/mayor. Rohingya refugees found in Aceh in 2015 were placed in temporary shelters at the Port of Kuala Langsa shortly after they were rescued by Acehnese fishermen. Before the enactment of President. Reg No. 125 In 2016, the Indonesian government, for humanitarian reasons, has provided temporary shelter facilities for Rohingya refugees including child refugees. Article 26 President. Reg No. 125 of 2016 requires that refugee shelters must meet several criteria including being close to health and worship service facilities, being in a district/city area with immigration detention centers, and accompanied 
by supporting security conditions. Child refugees have the privilege granted by Presidential Regulation No. 125 of 2016 because it is included in the category of refugees with special needs. Based on Article 27 paragraphs 1 and 3 of President. Reg No. 125 In 2016, child refugees can be placed outside shelters facilitated by the International Organization in the field of migration (in this case UNHCR) after obtaining permission from the minister. This can be understood because the need for facilities between adult refugees and child refugees is certainly different. Furthermore, it is regulated in Article 27 paragraph 4, that placement outside the shelter for refugee children is carried out to provide special care provided that children who become refugees are given care based on the principle of best interest for children who become refugees. There is no further explanation of what is meant by the principle of best interest.

President. Reg No. 125 of 2016 provides special protection for refugee children in terms of shelter without giving an age limit to the extent to which a person can still be classified as a child refugee. With no age limit for child refugees, it can refer to the age limit in the definition of a child contained in Article 1 paragraph 1 of Law No. 35 of 2014 concerning amendments to Law No. 23of 2002 concerning Child Protection namely someone who is not yet eighteen years old and includes a child in the womb. The next step taken after determining refugee shelters is to provide security for refugees. Based on Article 32 of Presidential Regulation No. 125 of 2016, safeguarding refugees in shelters is done by keeping refugees in shelters, creating a sense of security for the environment around shelters, and creating and socializing the rules of conduct that contain obligations and restrictions for refugees. It is important to pay attention to the safety of residents around the shelter, considering that refugees are foreigners who enter Indonesian territory with their respective backgrounds.

At present, safeguards against refugees at shelters have not been maximally implemented. This is evidenced by the large number of refugees who have fled from shelters to go to other areas. For example, the Blang Adoe shelter in North Aceh Regency, where previously it housed as many as 319 people, but as of May 2016, there were only 75 left. Some of those who came out of the shelter was known to be in Medan and some had entered Malaysia through illegal routes (Bonasir, 2016). Usually, the refugees who come out of the shelter use the services of several persons who promise to help the refugees out of Indonesian territory and go to a third country. The length of the process of granting refugee status and placement in third countries by UNHCR has caused many refugees to be tempted to leave Indonesia illegally.

A similar case occurred in May 2018 and repeated again in June 2018. A total of three Rohingya ethnic people who previously arrived on April 6, 2018, at the fishing port in East Aceh, disappeared. Allegedly, the three immigrants escaped from the shelter by being picked up by agents of the immigrant network in Langsa to be taken to Medan (Aceh Tribunnews, 2018). In December 2018, the case of Rohingya ethnic flight which was accommodated by the Indonesian Government was repeated. As many as 7 of the 79 Rohingya who were accommodated in the Cot Gapu SKB Complex, Bireuen, fled on 21 December 2018 (Aceh Tribunnews, 2018). The case of Rohingya refugees fleeing the shelter is often repeated. This fact shows the weak supervision of the Indonesian government. The weakness of the Indonesian Government's supervision is closely related to the lack of supervisory personnel or security officers. Another possibility is the condition of refugee camps that are not representative, making it difficult for officials to conduct surveillance or trigger refugees to flee. It should be noted that the purpose of safeguarding refugees at the shelter is not only to ensure that refugees will not escape from the shelter but also to create a sense of security for the environment around the shelter.

For refugees who enter Indonesia immigration surveillance will be carried out. Immigration control of refugees is carried out when found, in shelters and outside shelters, dispatched to destination countries, voluntary repatriation, and deportation. Article 33 President. Reg No. 125 of 2016 stated that immigration control is carried out by Immigration Detention Center officers). Immigration control for refugees at the shelter as well as outside the shelter is done by doublechecking refugee IDs and documents as well as fingerprinting. Furthermore, refugees will be given a special identity card for refugees. Article 35 and 36 of the President. Reg No. 125 of 2016 stated that refugees are required to report themselves every month to the Head of the Immigration Detention House to get a stamp on the identity card.

President. Reg No. 125 of 2016 regulates the handling of refugees from discovery to shelter. The regulation also regulates the security and immigration 
supervision of refugees, both adult and child refugees. With regard to child refugees, what is not regulated by the regulation is the operational standards for handling child refugees during the holding period and during the waiting period for the granting of refugee status by UNHCR. If this is not regulated, it is difficult to guarantee the rights of child refugees in Indonesia. For example, based on Article 9 of Law No. 35 of 2014, child refugees are entitled to education and teaching. Another thing that is also important to regulate is the mechanism for handling children who are separated from their parents or those who have been left dead by their parents. Implementing rules or operational standards for handling refugees are not only used to guarantee the rights of refugee children can be fulfilled but also protect the interests of the Government of Indonesia itself. Such rules will regulate in which cases the handling of child refugees is the responsibility of the Government of Indonesia in what cases are the responsibility of UNHCR. Such a regulation must pay attention to the ability of the Government of Indonesia because handling refugees will certainly require significant costs.

\section{CONCLUSION}

There are two important things that can be concluded from this study: first, that Presidential Regulation No. 125 of 2016 has not sufficiently fulfilled the rights of child refugees because it regulates the extent of handling refugees when found, the determination of shelter, security and immigration supervision. This is not enough to be used as a basis for handling refugees while in Indonesia, given the long waiting period for the release of refugee status. Second, many things need to be regulated such as what is permitted and prohibited by refugees while in the provided shelter. Indonesia needs additional rules regarding operational standards for handling refugees that regulate what can be done and prohibited by refugees while in shelters. This is closely related to the guarantee of refugee rights by Indonesia including child refugees. Indonesia must immediately make implementing regulations from President. Reg No. 125 of 2016 to explicitly determine the extent that Indonesia is responsible for fulfilling the rights of child refugees in Indonesia. Such rules will also provide clarity for child refugees to whom they claim their rights. Implementing rules also include arrangements for what refugees and children in Indonesia can do and are prohibited from doing while waiting for refugee status to be obtained.

\section{REFERENCES}

Aceh tribunnews. (2018). Empat Warga Rohingya di Langsa Menghilang (Four Rohingya Refugees in Langsa Disappear). Aceh tribunnews, Friday, June 29, 2018. Retrieved from http://aceh.tribunnews.com/2018/06/29/empat-wargarohingya-di-langsa-menghilang

Aceh tribunnews. (2018). Tujuh Pengungsi Rohingya Kabur. Aceh tribunnews, Saturday, December 22, 2018. Retrieved from http://aceh.tribunnews.com/2018/12/22/tujuh-pengungsirohingya-kabur

Afriansyah, A. (2018). Indonesia and the Global Compacts on Refugees and Migration. International Journal of Refugee Law, 30(4), 684-686. https://doi.org/10.1093/ijrl/eey066

Armandhanu D. (2016). Forbidden by land, Rohingya refugees drown in the sea. CNN Indonesia, Thursday, April 21, 2016. Retrieved from https://www.cnnindonesia.com/internasional/2016042113551 8-106-125543/dilarang-lewat-jalur-darat-warga-rohingyatenggelam-di-laut

Bonasir R. (2016). Pengungsi Rohingya di Aceh 'Mungkin Akan Habis' Sebelum Setahun, BBC Indonesia, February 28, 2016. Retrieved from http://www.bbc.com/indonesia/berita_indonesia/2016/02/160 227_indonesia_pengungsi_rohingya_tenggat

Briskman, L. R., \& Fiske, L. I. (2016). Asylum seekers and refugees in Indonesia: Problems and potentials. Cosmopolitan Civil Societies: An Interdisciplinary Journal, 8(2), 22-42. https://doi.org/10.5130/ccs.v8i2.4883

Brown, T. (2017). After the Boats Stopped: Refugees Managing a Life of Protracted Limbo in Indonesia. Antropologi Indonesia, 34-50.

https://doi.org/10.7454/ai.v38i1.8755

Devetak, R. (2004). In fear of refugees: The politics of border protection in Australia. The international journal of human rights, 8(1), 101-109. https://doi.org/10.1080/1364298042000212565

Jeffers, A. (2012). Refugees, theatre and crisis: Performing global identities. Palgrave Macmillan. https://doi.org/10.1057/9780230354821

Joko Priyono, F.X., \& Sudiro, A.P. (2020). Intergovernmental cooperation mechanisms in combating transnational human trafficking within ASEAN. Academic Journal of Interdisciplinary Studies 9(2), 120-126. https://doi.org/10.36941/ajis-2020-0029

Molana, D. H. (2018). Sebelum ke Aceh, Pengungsi Rohingya Ditolak Thailand dan Malaysia (Prior to Aceh, Rohingya Refugees Rejected by Thailand and Malaysia). Detik news, Saturday, Apr $212018 . \quad$ Retrieved from https://news.detik.com/berita/d-3982789/sebelum-ke-acehpengungsi-rohingya-ditolak-thailand-dan-malaysia

Moussalli, M. (1992). Handbook on Procedures and Criteria for Determining Refugee Status under the 1951 Convention and the 1967 Protocol relating to the Status of Refugees. Geneva: Office of the United Nations High Commissioner for Refugees.

Pasuhuk, H. (2015). Nelayan Aceh Selamatkan 800 Pengungsi Rohingya dan Bangladesh (Acehnese Fishermen Save 800 Refugees from Rohingya and Bangladesh). DW Indonesia, May 15, 2015. Retrieved from http://www.dw.com/id/nelayanaceh-selamatkan-800-pengungsi-rohingya-danbangladesh/a-18451487

Shahnaz, L., Nurvianti, D., \& Zein, Y. A. (2019). The Political Law of Presidential Regulation on the Handling of Refugees in Indonesia. US-China L. Rev., 16, 65 . https://doi.org/10.17265/1548-6605/2019.02.003

UN General Assembly. (1951). Convention relating to the status of refugees. United Nations, Treaty Series, 189, 137. 
UN General Assembly. (1989). Convention on the Rights of the Child. United Nations, Treaty Series, 1577(3).

UNHCR Asia Pacific. (n.d). UNHCR Emergencies. Retrieved from https://www.unhcr.org/emergencies.html
Zimmermann, A., Dörschner, J., \& Machts, F. (Eds.). (2011). The 1951 Convention relating to the status of refugees and its 1967 protocol: A commentary. Oxford University Press. https://doi.org/10.1093/actrade/9780199542512.001.0001

https://doi.org/10.6000/1929-4409.2021.10.111

(c) 2021 Titik Suharti; Licensee Lifescience Global.

This is an open access article licensed under the terms of the Creative Commons Attribution Non-Commercial License (http://creativecommons.org/licenses/by-nc/3.0/) which permits unrestricted, non-commercial use, distribution and reproduction in any medium, provided the work is properly cited. 